\title{
Bacteria-Affecting Cephalopods
}

\author{
Rosa Farto, Gianluca Fichi, Camino Gestal, Santiago Pascual, \\ and Teresa Pérez Nieto
}

\begin{abstract}
Bacterial pathogens contribute to obtain an unsuccessful production of cephalopods. An updated overview of the knowledge of these pathogens must be a valuable tool to improve their aquarium maintenance and aquaculture. The present work provides a description of the main bacterial pathogens associated with larval stages of cultured Octopus vulgaris, and juvenile and adults of several cephalopods. Vibrio species, reported with ability to cause vibriosis in aquaculture, are the main bacteria associated with skin lesions in adults. Different species of Pseudomonas and Aeromonas, among others, have also been detected. Furthermore, gram-positive bacteria such as Bacillus have been also described. Among them, $V$. alginolyticus, $V$. carchariae, V. parahaemolyticus, $V$. splendidus and $V$. lentus have also been isolated from sterile organs or fluids of animals and their potential as invaders proved. However, only $V$. alginolyticus or $V$. lentus has the ability to cause lesions, and, in addition, the last one is proved as the causative agent of death in octopuses. Other organs such as eyes of squids are also colonized by Vibrio species or Micrococcus sp., and recently Photobacterium swingsii and Lactococcus garvieae have been reported associated with a retrobulbar lesion in octopus. Rickettsial-like organisms (RLO) are also detected in the gills of the octopus, having a detrimental effect on the respiratory gaseous exchange of the animals. Cultures of octopus paralarvae show a genetically diverse community comparable to those reported previously from other marine hatcheries. Bacteria included in the Splendidus clade is the dominant group in all conditions, except in one of them, where V. alginolyticus, $V$. proteolyticus or Pseudomonas
\end{abstract}

R. Farto $(\bowtie) \cdot$ T. P. Nieto

Marine Research Centre (CIM-UVIGO), University of Vigo,

36331 Vigo, Pontevedra, Spain

e-mail: rfarto@uvigo.es

T. P. Nieto

e-mail: mtperez@uvigo.es

G. Fichi

Istituto Zooprofilattico Sperimentale delle Regioni Lazio e

Toscana, 56123 Pisa, Italy

e-mail: Gianluca.fichi@gmail.com

C. Gestal

Aquatic Molecular Pathobiology Group, Institute of Marine

Research, Spanish National Research Council (CSIC), 36208

Vigo, Pontevedra, Spain

e-mail: cgestal@iim.csic.es

S. Pascual

Ecology and Biodiversity Department, Institute of Marine

Research, Spanish National Research Council (CSIC), 36208

Vigo, Pontevedra, Spain

e-mail: spascual@iim.csic.es 
fluorescens are the main detected groups. Furthermore, Shewanella or Pseudoalteromonas undina have also been identified. All this shows that pathogenic bacteria are frequent microorganisms associated with aquarium maintenance and culture of cephalopods, and special attention on maintaining a well-balanced community of microorganisms should be applied.

\section{Keywords}

Cephalopod diseases - Paralarvae - Microbial community - Pathogenic bacteria • Splendidus clade $\cdot$ Rickettsia-like organisms

\subsection{Introduction}

Incidence of diseases, several of them caused by bacteria, is one of the most important problems which avoid obtaining a successfully production in the aquaculture of cephalopods or its suitable maintenance in captive conditions (García-Fernández et al. 2016; Sykes and Gestal, 2014).

Knowledge on bacterial species associated with cephalopods culture and its ecological role would be essential for improving industrial culture production. Seawater have a variable microscopic population density (Harder 2009), and it contains a high microbial diversity depending on physico-chemical and geographic factors such as the temperature of the water, latitude and salinity. The ability of bacteria to colonize surfaces (epibiotic bacteria) is very well documented, and they comprise well-organized bacterial communities associated with marine organisms, which are influenced by temporal changes in the environment. However, some bacteria are specifically and persistently associated with particular marine animals, and they are not found in seawater or on other animals (Thakur et al. 2004; Sharp et al. 2007). This can explain the species-specific vulnerability to pathogens previously suggested for Octopus bimaculoides and $O$. maya (Hanlon and Forsythe 1990). These 'microepibionts' are multi-functional and are involved in obtaining nutrients, acquiring new genetic traits and providing some measure of chemical defence against pathogens (Wahl et al. 2012). In these epiphytic communities, developing biofilms is the most common, and quorum sensing modulates behaviour of many biofilm-associated bacteria, affecting symbiotic relationships and host interactions (Maximilien et al. 1998; Parsek and Greenberg 2005). Co-infection is another important factor affecting bacterial diseases, in fact in previous studies parasite infection enhanced bacterial invasion in fish (Rodríguez-Quiroga et al. 2016).

Differences in culturable bacteria most frequently isolated from skin of apparently healthy, wild or laboratorymaintained adult squids have been previously found. In fact, a higher diversity is shown in the former ones (Hanlon and Forsythe 1990). Similar data are observed in the gastrointestinal microbiome of wild octopus paralarvae with respect to that of reared ones (Roura et al. 2017). Although aquaculture systems are designed to imitate the natural environment, the maintenance of adequate conditions during all culture production is problematic. Furthermore, diets provided are less diverse than in natural media. Therefore, it can produce alterations in microbial community of seawater and/or surface (external or internal) of cephalopods. This provides an opportunity for the dominance of bacteria, which show the ability to invade the host, and in the end, to cause a fatal infection. On the other hand, this is also facilitated when the surface of the animal is injured.

In 1990, Hanlon and Forsythe described the main bacterial pathogens associated with juvenile and adults. In fact, they included data from published literature, and their own data collected from analyses resultant of 14 species of different cephalopods for 13 years. Species of Vibrio, mainly, but also members of the genera Pseudomonas, Aeromonas, Staphylococcus or Streptococcus, among others, have been associated with healthy octopuses or squids in nature. Some of these genera have also been associated with the ulcerated skin of octopuses and squids from their natural environment or laboratory-maintained, being this, their route of entrance in animals, and progressing later until a fatal infection. Furthermore, a possible food-borne was the suggested route of entrance for $V$. carchariae, which was associated with sudden death of laboratory-maintained octopuses, which showed lack of any external of behavioural symptoms. Similarly, an unknown route of entrance, not associated with ulcerated skin, was proposed for cuttlefish which suffered a highly virulent systemic infection. Squids with eye damage associated with bacteria were also reported, but no further information on the route of infection was given. However, it is unknown if bacteria are the initial cause of infection, with the exception of one study, where $V$. alginolyticus was proved as causation of lesions in octopus. Similarly, there is a lack of information on culturable bacteria associated to different stages of cephalopods in reared conditions.

In attempting to be comprehensive, we reviewed the knowledge about bacterial disease in the most representative European cephalopod species to date, detailing the main bacterial pathogens associated with juvenile or adults. 
Furthermore, data from bacterial associated with larval stages of cultured octopuses (unpubl.), recently qualitatively sampled 'in situ' by us were also included.

The common signs caused by bacteria on cephalopods, and, when possible, images, are shown. In addition, it is included a brief description of characteristics of bacteria, diagnostic and treatments used against bacteria.

\subsection{Potential Pathogenic Bacteria for Larval Development Stages}

Bacterial septicaemia was occasionally observed in paralarvae (13-15 days old) of $O$. vulgaris reared in aquaculture tanks, which could be causative of the dead of the paralarvae (Fig. 8.1a, b). The identification of the aetiological agent was not established by the authors. Seawater quality, and maintenance and cleaning precautionary measures were suggested as factors that could facilitate the growth of pathogenic bacteria that as a result caused the infection. Previous studies have revealed that uncontrolled factors in the culture have an important impact on the establishment and evolution of the microbial community in the culture tanks of Artemia (Verschuere et al. 1997). Similar results were also found for culture of clams (Kwan and Bolch 2015). It was also shown that an effective balance of microbial populations included in the same community ensures the final rearing success (Verschuere et al. 1997; Kwan and Bolch 2015; Shi et al. 2017).

Recently, it has been proved that the intestinal microbiome, highly diverse, of octopus paralarvae reared in captivity and feed with Artemia is rapidly become less diverse and is mainly suggested as a consequence of culture conditions (Roura et al. 2017). However, to date, there is an absence of published data available on diversity of bacteria from cephalopod hatcheries. Recent qualitative preliminary analysis of seawater associated with different stages of $O$. vulgaris hatchery culture has focused to characterize and identify the culturable bacteria.

\subsubsection{Microbial Community Counts}

\subsubsection{Water Samples}

Culturable bacteria was isolated on three different dates corresponding to Experiment 1, 2 and 3 from seawater associated with different stages of an $O$. vulgaris culture in Galicia (Table 8.1). After 13-15 days of paralarvae culture, samples were taken on the same day in all stages of each Experiment. Seawater inside the hatchery was filtered until $1 \mu \mathrm{m}$ for all experiments, but in addition, a high wattage UV treatment was also applied for Artemia (Artemia salina) culture. Moreover, seawater filtered until $20 \mu \mathrm{m}$ and treated with low wattage UV was analysed for comparative purposes (Experiment 4). Standard conditions of natural photoperiod, seawater temperature $\left(19-23{ }^{\circ} \mathrm{C}\right)$ and salinity of $33 \%$ were maintained.

Larval tanks $(1000 \mathrm{~L})$ containing 5 larvae $1^{-1}$ were reared following the protocol described by Iglesias et al. (2004). In this study, paralarvae were fed with Artemia nauplius or Artemia nauplius complemented with Maja brachydactyla zoeas or freeze-dried feed (made from different species of crustaceans).

Water samples $(1 \mathrm{ml})$ were serially diluted in sterile seawater and spread out $(0.1 \mathrm{~mL})$ over plates of Tryptic Soy Agar supplemented up to $1 \%$ (w/v) $\mathrm{NaCl}$ (TSA-1) and ThiosulphateCitrate-Bile-Sucrose (TCBS) in duplicate. Colonies were counted after 4 days of incubation at $22{ }^{\circ} \mathrm{C}$, and the results expressed in colony-forming units (CFU) per $\mathrm{ml}$. Whereas TSA-1 was used for total heterotrophic bacteria counts, TCBS was for presumptive Vibrio ones. The last one was used since Vibrio species are a significant component of culturable marine bacterial populations (Thompson et al. 2004; Montes et al. 2006; Beaz-Hidalgo et al. 2008; Guisande et al. 2008).

Colonies of each morphology from TSA-1 or TCBS were picked off and spread on TSA-1 to obtain pure cultures, and then inoculated on Tryptic soy broth with $1 \%$ (w/v) $\mathrm{NaCl}$ and $15 \%(\mathrm{v} / \mathrm{v})$ of glycerol for their conservation at $-80{ }^{\circ} \mathrm{C}$.

\subsubsection{Microbial Counts}

Total heterotrophic bacteria associated with the octopus cultures are shown in Table 8.1. The results showed that
Fig. 8.1 O. vulgaris paralarvae reared in aquarium conditions. a Histological section of the connective tissue of paralarvae infected by bacteria (arrow). b Detail showing the strong septicemia observed in the whole paralarvae. H\&E stain. Images $\mathbf{a}$ and $\mathbf{b}$ by courtesy of Dr. R. Fernández-Gago. Scale bars a, b $20 \mu \mathrm{m}$
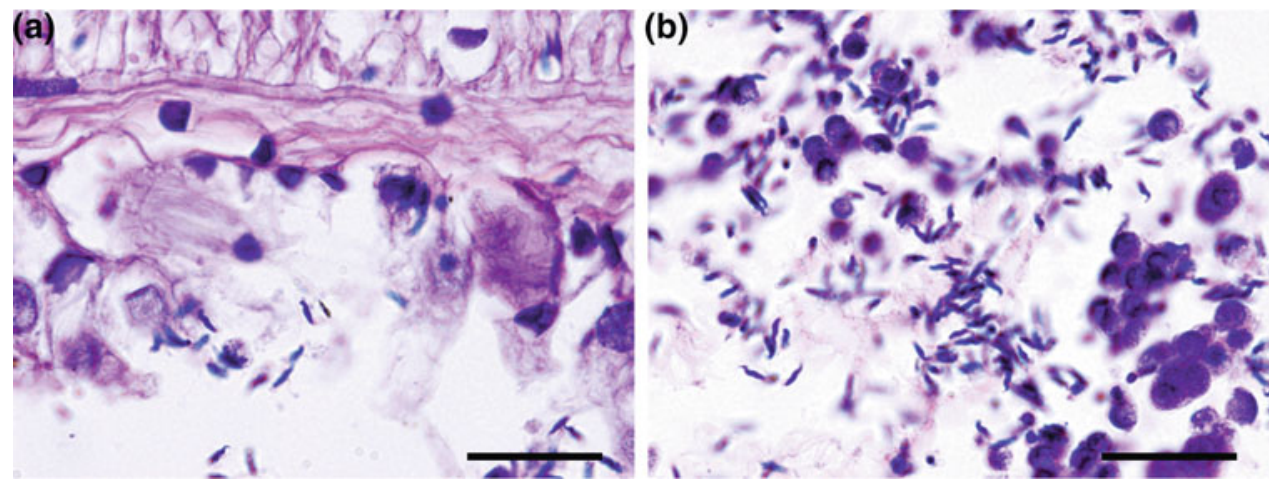


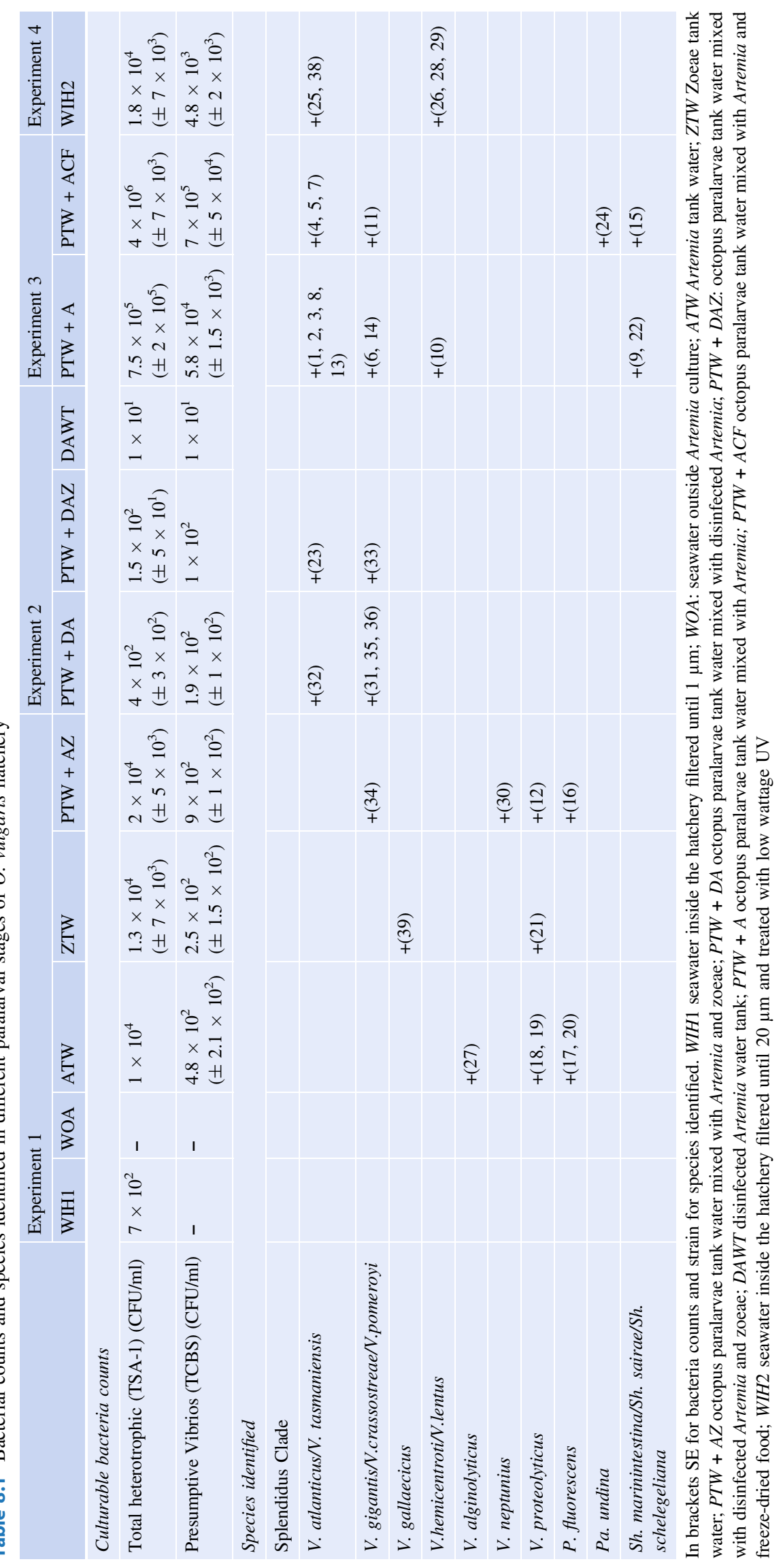


there are strong evidences that the food (live or freeze-dried) supplied to the larvae constitutes the main source of the bacteria associated to the cultures of the octopus larvae.

A significant percentage (50-75\%) of total heterotrophic bacteria grew in TCBS, and as it was confirmed in this study, most of them were included in genus Vibrio (Table 8.1). Their counts remained uniform in most of the culture conditions studied. The lowest value was detected in the cultures treated with disinfectant, whereas the highest was detected in that containing Artemia mixed with freeze-dried feed. These results are in agreement with those of scallop larval culture, where concentrations of Vibrio varied only between $10^{2}$ and $10^{3}$ cels $\mathrm{ml}^{-1}$ (Nicolas et al. 1996). However, higher counts from a culture water of Artemia $\left(10^{3}-10^{4} \mathrm{cfu} \mathrm{ml}^{-1}\right)$ were detected in early times of the culture period (Verschuere et al. 1997). Variations in Vibrio counts are frequent in hatcheries. In fact, an increase of Vibrio counts associated to clam's hatchery was previously found after the rise of environmental temperature (Mechri et al. 2012).

Finally, in Experiment 4, the total heterotrophic bacteria and the presumptive Vibrio were increased in 2-log or 3-log units, respectively, with respect at those from water inside the hatchery used for larval culture. Variations in the treatment of the seawater (mainly due to filtration) could explain these results.

\subsubsection{Characterization of Culturable Bacteria Associated with Octopus Paralarvae Culture}

To carry out the characterization of bacteria associated with the different culture conditions studied, a total of 38 strains corresponding to the colonies that had different morphologies on TSA-1 or TCBS were selected. For their characterization, primary and secondary identification biochemical tests and PCR with specific primers were performed, but the final identification and/or assignation to closely related species was performed by sequencing of $16 \mathrm{~S}$ rRNA gene.

All strains were characterized by phenotypical tests and only 30 by sequencing of $16 \mathrm{~S}$ rRNA gene. The closest-neighbouring species, which shared a similarity value in the $16 \mathrm{~S}$ rRNA sequences of $\geq 98 \%$, were used to identify the isolates. Molecular identification was assigned to the remaining strains (8), when the strains identified by $16 \mathrm{~S}$ rRNA and the unidentified ones shared the same phenotypical profile.

\subsubsection{Phenotypical Characterization}

Firstly, the strains were phenotypically characterized by using a set of primary identification tests: gram staining, motility, oxidase, catalase, oxidative or fermentative glucose metabolism on $\mathrm{O} / \mathrm{F}$ Basal Medium (O/F), growth ability at
$0 \% \mathrm{NaCl}$ or in TCBS and susceptibility to $\mathrm{O} 129$ vibriostatic agent (2, 4-diamino-6, 7-di-isopropylpteridine phosphate; $150 \mu \mathrm{g} / \mathrm{disc})$.

These assays indicated that all the strains were gram-negative motile rods and that they were positive for all tests except for being able to grow at $0 \% \mathrm{NaCl}$ and the glucose metabolism. The two last tests allowed discriminating three groups of strains; (1) strains showing aerobic/anaerobic glucose metabolism, being all of them unable to grow at $0 \% \mathrm{NaCl}$ (facultative anaerobes); (2) strains without aerobic/anaerobic glucose metabolism, being all of them unable to grow at $0 \% \mathrm{NaCl}$; (3) strains without oxidative/fermentative glucose metabolism (aerobes), but with ability to grow at $0 \% \mathrm{NaCl}$.

All these tests presumptively grouped all facultative anaerobes in genus Vibrio. All of them were able to grow well on TCBS and allowed discriminating between strains with ability to use sucrose (Table 8.2). Although, this medium is used for the isolation of Vibrio spp., it is also possible, but with poor growth, for other genera (Guisande et al. 2004). In fact, this was the case for our bacteria identified as $P$. fluorescens.

In order to confirm this presumptive identification, secondary biochemical tests were performed for the anaerobic facultative group by using the commercial phenothypic test API 20E (BioMerieux) (Table 8.2). This system is frequently used for the identification of fish pathogens, since its database includes an important number of them. However, it is well known that several reactions, among them decarboxylases [arginine dehydrolase (ADH), lysine decarboxylase (LDC), ornithine decarboxylase (ODC)], must be compared with conventional biochemical tests, since if there are differences, data from the last are preferable as reference (Buller 2004; Popovic et al. 2007). In addition, they were also included in this study, and they were determined as described by Montes et al. (1999). Presence of Vibrio was confirmed by the system, and its database allowed determining that the strains were closely related to $V$. alginolyticus, $V$. proteolyticus and V. splendidus.

It is well known that $V$. splendidus is phylogenically closely related to other species all of them termed as $V$. splendidus-related group (Splendidus clade), which is the most diverse among Vibrionales (Sawabe et al. 2007). API $20 \mathrm{E}$ was unable to discriminate these species since strains included in the same group showed variable biochemical profiles (Table 8.2). It is also difficult by using numerical taxonomy or molecular methods (Lago et al. 2009; Revised by Oden et al. 2016).

\subsubsection{Molecular Characterization}

In a previous study, the combined specificity of $V$. tasmaniensis (VTS/VT) and V. splendidus (VTS/VS) primer sets offered the best coverage $(86 \%)$ in terms of separating 
Table 8.2 Characterization and Identification of Vibrio strains associated with of Octopus vulgaris hatchery

\begin{tabular}{|c|c|c|c|c|c|c|c|}
\hline & \multicolumn{7}{|c|}{ Groups identified by sequencing assignment ${ }^{\mathrm{a}}$} \\
\hline & \multicolumn{4}{|l|}{ Splendidus clade } & \multirow[t]{2}{*}{ V. alginolyticus } & \multirow[t]{2}{*}{ V. neptunius } & \multirow[t]{2}{*}{ V. proteolyticus } \\
\hline & $\begin{array}{l}\text { V. atlanticus/ } \\
\text { V. tasmaniensis }\end{array}$ & $\begin{array}{l}V . \text { gigantis/ } \\
V . \text { crassostreael } \\
V . \text { pomeroyi }\end{array}$ & V. gallaecicus & $\begin{array}{l}V . \text { hemicentroti/ } \\
V . \text { lentus }\end{array}$ & & & \\
\hline \multicolumn{8}{|l|}{ Tests to identify strains } \\
\hline $\begin{array}{l}\text { Sequence (16S rRNA) } \\
\text { identity (\%) with the } \\
\text { closest neighbour }\end{array}$ & $\geq 98.7 \%$ & $\geq 99.5 \%$ & $99.8 \%$ & $>98.5 \%$ & $99.9 \%$ & $99.9 \%$ & $99.9 \%$ \\
\hline \multicolumn{8}{|c|}{ Amplification with specific primers } \\
\hline $\begin{array}{l}\text { VTS/VT ( } V . \\
\text { tasmaniensis) }\end{array}$ & $+(10 / 12)$ & $+(4 / 8)$ & + & $+(1 / 4)$ & - & - & - \\
\hline VTS/VS (V. splendidus) & $+(4 / 12)$ & $+(4 / 8)$ & - & - & - & - & - \\
\hline VN1/VN2 (V. neptunius) & - & - & - & - & - & + & - \\
\hline \multicolumn{8}{|l|}{ Biochemical characteristics } \\
\hline TCBS $(\text { sucrose }+)^{\mathrm{b}}$ & $+(8 / 12)$ & $+(4 / 8)$ & - & - & + & + & - \\
\hline TCBS (sucrose -$)^{\mathrm{b}}$ & $+(4 / 12)$ & $+(4 / 8)$ & + & $+(4 / 4)$ & - & - & $+(3 / 3)$ \\
\hline $\begin{array}{l}\text { Arginine dihydrolase } \\
(\mathrm{ADH})^{\mathrm{b}}\end{array}$ & + & + & + & + & - & + & + \\
\hline $\begin{array}{l}\text { Lysine decarboxylase } \\
(\mathrm{LDC})^{\mathrm{b}}\end{array}$ & - & - & - & - & + & - & + \\
\hline $\begin{array}{l}\text { Ornithine decarboxylase } \\
(\text { ODC })^{\mathrm{b}}\end{array}$ & - & - & - & - & + & - & - \\
\hline ß-galactosidase ${ }^{c}$ & $+(4 / 8)$ & $+(7 / 8)$ & - & + & - & - & - \\
\hline Gelatinase $^{c}$ & $+(5 / 8)$ & + & - & + & + & + & + \\
\hline Citrate utilization $^{c}$ & $-(5 / 8)$ & - & - & - & - & + & + \\
\hline Voges Proskauer $^{\mathrm{c}}$ & - & - & - & - & + & - & + \\
\hline $\mathrm{NO}_{2}$ production $^{\mathrm{c}}$ & + & + & + & + & + & - & + \\
\hline \multicolumn{8}{|l|}{ Fermentation/Oxidation $^{c}$} \\
\hline Amygdalin & + & $+(5 / 8)$ & + & $+(1 / 2)$ & + & + & - \\
\hline Arabinose & $-(7 / 8)$ & - & - & - & - & - & - \\
\hline Inositol & + & $+(7 / 8)$ & + & + & + & - & + \\
\hline Melibiose & $-(6 / 8)$ & $-(7 / 8)$ & - & - & - & - & - \\
\hline Rhamnose & $+(5 / 8)$ & $-(5 / 8)$ & - & - & + & - & - \\
\hline Sorbitol & $+(7 / 8)$ & $+(6 / 8)$ & - & $+(1 / 2)$ & + & - & + \\
\hline Sucrose & $+(5 / 8)$ & $+(6 / 8)$ & - & - & + & + & $+(2 / 3)$ \\
\hline
\end{tabular}

${ }^{a}$ Multiple alignment of sequences was created by ClustalW in Genious Editor version 12.0.6 (Biomatters; http://www.geneious.com/). This included 1.138 positions after the removal of ambiguous ones. A phylogenetic tree was constructed using Molecular Evolutionary Genetics Analysis (MEGA) version 6 (Tamura et al. 2013). This was performed using the neighbour-joining method and Tamura-Nei distance model, with the calculation of cluster stability by bootstrap analysis with 1000 replicates. All available species of each genus closest to studied strains were selected

${ }^{\mathrm{b}}$ Tests performed by using conventional biochemical tests

${ }^{\mathrm{c}}$ Tests performed by using API 20E. All strains were negative for $\mathrm{H}_{2} \mathrm{~S}$ production, hydrolysis of urea or presence of tryptophane deaminase; and they were positive for indole production and fermentation/oxidation of D-glucose or D-mannitol (all of them performed by using API $20 \mathrm{E}$ ). In brackets number of positive or negative strains of all assayed

several of the species included in the Splendidus clade, and from other Vibrio species (Lago et al. 2009). In this study, a positive amplification was shown in all strains which were characterized in the Splendidus clade, except in six $(13,26$, $28,29,31,33)$. In fact, from the positive ones, $84 \%(16 / 19)$ and $42 \%(8 / 19)$ of strains reacted with VTS/VT and VTS/VS primer sets, respectively (Table 8.2). Negative amplification was shown by the remaining strains characterized as Shewanella (Sh.) or Pseudomonas; on the contrary, a positive amplification with the primer set VTS/VT was shown by strain 24 , which was identified by $16 \mathrm{~S}$ rRNA gene analyses as Pseudoalteromonas $(\mathrm{Pa}$.$) undina. Furthermore, a$ 
$V$. neptunius primer set was highly specific, showing only cross-reaction with $V$. parahaemolyticus species from 44 tested species (Lago et al. 2009). Similarly, in this study only one strain, which was identified by $16 \mathrm{~S}$ rRNA gene analyses as $V$. neptunius, was positive (Table 8.2). Since these primer sets were developed, the number of species included in the Splendidus clade has increased (revised by Oden et al. 2016). In this study, it is shown that they have cross-reaction with them. Nevertheless, these results revealed that the primer sets are a valuable tool for a fast detection of Splendidus clade, and to separate this clade from other Vibrio species.

Additionally, a sequencing of $16 \mathrm{~S}$ rRNA gene analyses was performed according to the method described by Guisande et al. (2008), in order to confirm all these results. The strains assigned to each phylogenetic group are shown in Table 8.1, and the sequence identity (\%) with the closest neighbour in Table 8.2. These results allowed to confirm that $81 \%$ (31 of a total of 38 strains) of strains were facultative anaerobes, and the remaining was aerobic. Among facultative anaerobic bacteria, the dominant genus identified was Vibrio (100\%). The highest number (63.2\%) of Vibrio strains was included in Splendidus clade, and they were assigned to different groups depending on their closest similarity with species (Table 8.2). In addition, one strain was identified as $V$. gallaecicus.

The 16S rRNA gene analyses allowed a more complete identification since $V$. gallaecicus, $V$. neptunius, $V$. proteolyticus, $P a$. undina and $P$. fluorescens were identified. Furthermore, several strains were shown more closely related to specific species of Splendidus clade, $V$. alginolyticus or Shewanella.

\subsubsection{Pathogenicity of Culturable Bacteria Associated with Octopus Paralarvae Culture}

The Splendidus clade is the most abundant in marine samples associated with several marine animals, water column, occurring in bacterioplankton and sediments (revised by Pérez-Cataluña et al. 2016), and also are part of regular components of farmed aquatic animal microbiota (Montes et al. 2003; Guisande 2004; Baez et al. 2008; Kwan and Bolch 2015; Oden et al. 2016).

In this study, these strains were the most abundant in all culture conditions analysed, except in the conditions of Experiment 1, where dominant groups were strains identified as $V$. proteolyticus, $V$. alginolyticus or P. fluorescens. Similarly, $V$. alginolyticus was also the predominant species associated with clam or gilthead sea bream hatcheries (Snoussi et al. 2006; Mechri et al. 2012); P. fluorescens was also found associated with the sea bream hatchery, and it was one of the autochthonous denitrifying bacterium isolated from marine biofilters at a recirculation aquaculture system (Snoussi et al. 2006; Borges et al. 2008). Other species of Pseudomonas were also associated with oyster larvae (Farto et al. 2006) and with Artemia culture (Verschuere et al. 1997). Finally, Shewanella or Pa. undina were also identified associated with culture water containing octopus paralarvae and commercial feed or Artemia of this study. These groups were also previously found from healthy oyster cultures (Farto et al. 2006).

It is well known that several of the groups isolated in this study may have a role in larval mortality in cultures. In fact, several bacterial included in the Splendidus clade are considered pathogenic for bivalve molluscs (oyster, clam, scallop, mussel) (Revised by Beaz-Hidalgo et al. 2009; Revised by Kwan and Bolch 2015; Vanhove et al. 2015; Cheikh et al. 2016) and also cephalopod molluscs (Farto et al. 2003; Iehata et al. 2016). Similarly, V. alginolyticus was pathogenic for carpet shell clam larval and juvenile (Gómez-León et al. 2005; Mechri et al. 2015), fish (Liu et al. 2004; Zheng et al. 2017), crustacean (Jayaprakash et al. 2006; Xu et al. 2013), scallop (Riquelme et al. 1996), red abalone (Anguiano-Beltrán et al. 1998), associated with infected Chilean octopus eggs (Iehata et al. 2016), with ability to cause skin lesions to young octopus (Hanlon and Forsythe 1990), and isolated from skin ulcers and/or different organs of cultured cuttlefish (Sangster and Smolowitz 2003). V. proteolyticus has been previously identified as part of the Vibrio consortium isolated from diseased corals (Cervino et al. 2008), and were identified as pathogens of Artemia spp. (Verschuere et al. 2000). Another pathogen described for Artemia sp. is V. neptunius (Verschuere et al. 2000; Austin et al. 2005), being also for oyster (Prado et al. 2005; Guisande et al. 2008). There are several strains of Pa. undina described as biological controllers of virus (Maeda et al. 1997), however, other were pathogens for gilthead sea bream or scallop (Pujalte et al. 2007; Sandaa et al. 2008). The genus Pseudoalteromonas was also previously found associated with infected Chilean octopus eggs (Uriarte et al. 2011; Iehata et al. 2016).

Then, although there is an absence of published data available from octopus hatcheries, the culturable species observed are comparable to those reported previously from other marine hatcheries. This diversity resembles that of coastal seawater (Thompson et al. 2005), and several of them can cause mortality in hatchery production. Previous studies have shown that differences in dominance of a specific group can be explained by variations in interactions within the total bacterial community due to alterations in environmental conditions of cultures. Those changes can encourage dominance and diversity of more virulent species (Kwan and Bolch 2015). So, in our study, all cultures of octopus larvae analysed showed similar levels of mortality, and also a 
genetically diverse community, but different between Experiment 1 and Experiments 2-3.

Further studies are needed to understand the equilibrium among a community of microorganisms, and how changes in husbandry practices select for more virulent genotypes.

\subsection{Potential Pathogenic Bacteria for Juvenile and Adults}

Several bacteria have been associated with diseased cephalopods (octopuses, squids and cuttlefish). Although most of them have been isolated from skin lesions, they were also from sterile organs or fluids (gill heart, reproductive organs, haemolymph) and others (eye). Particularly, mainly several species of Vibrio, such as $V$. alginolyticus, $V$. parahaemolyticus, V. splendidus or V. lentus, and recently Photobacterium (Ph.) swingsii and L. garvieae have been reported. This fact confirms their potential as invaders, and also the positive septicaemia described in several cases, which is associated with advanced stages of infection. The halting of disease progression and the promotion of healing, after antibiotic treatment of several animals, also show a role of bacteria in diseases of animals (Hanlon and Forsythe 1990; Sherrill et al. 2000; Sangster and Smolowitz 2003). However, most of bacteria were not confirmed as the cause of death of animals, and it is uncertain if they were the initial cause of infection. In this section, a brief reference to those bacteria not confirmed as the causative agent of death and/or the initial cause of infection are included.

\subsubsection{Miscellaneous Bacteria Associated with Skin Lesions}

There are several studies showing a variety of bacteria with ability to colonize skin lesions in octopus maintained in captivity. Crowding and increased contact among cultured octopus are proposed as the more probable cause of physical injury, developing into ulcerations due to colonization of bacteria, which would induce a fatal infection affecting multiple organs in the same individual, if untreated. Similarly, this would be the process for wild-caught squids maintained in the laboratory or cuttlefish maintained during a 12-year period in exhibition aquariums. Furthermore, several captured wild octopuses displayed skin lesions, which became worse under laboratory conditions (Hanlon and Forsythe 1990; Sherrill et al. 2000; Farto et al. 2003).

The clinical signs most frequently described for octopus include skin ulcers in the head through which bacteria penetrate, progressing into an advanced infection stage showing deep wounds in arms or head mantle of octopus (Hanlon and Forsythe 1990; Farto et al. 2003).

Previously, until 36 bacteria species had been isolated from skin ulcers of diseased octopuses or squids, most of them from cultured conditions. Particularly, the majority corresponded to gram-negative bacteria. From these, the mainly ones were different species from the genus Vibrio with ability to cause vibriosis such as $V$. anguillarum, $V$. alginolyticus, V. parahamolyticus and V. splendidus. Different species of Pseudomonas and Aeromonas, and presumptive Cytophaga-like strains were also detected. Furthermore, gram-positive bacteria were also detected such as Bacillus and Staphylococcus (Hanlon and Forsythe 1990; Farto et al. 2003; Tsai et al. 2012; Fichi et al. 2015). However, only $V$. alginolyticus or $V$. lentus have been confirmed with ability to cause lesions in octopus (Hanlon and Forsythe 1990; Farto et al. 2003). All these studies have also shown that is frequent that skin lesions contain different species of bacteria simultaneously.

A brief description of several bacteria indicated in this section is shown below.

\section{Vibrio alginolyticus and Vibrio parahaemolyticus}

Both $V$. alginolyticus and $V$. parahamolyticus are motile gram-negative bacteria in Vibrionaceae family, Gammaproteobacteria class, which have been isolated frequently from marine and coastal waters throughout the world. Particularly, in a clam hatchery located in the Mediterranean coast has been shown that $V$. alginolyticus strains were the most dominant, and $V$. parahaemolyticus strains represent only $2 \%$ of all Vibrionaceae isolated (Mechri et al. 2012). Both have been associated with marine organism's diseases, and molluscs among them. This is detailed for $V$. alginolyticus in Sect. 8.2 (Pathogenicity). Furthermore, an exhaustive description of infection stages of this species was previously reported for cultured sepoids, suggesting, in addition to skin lesion, other routes of entrance in animals (Sangster and Smolowitz 2003). On the other hand, in diseases affecting small abalone, Spanish toothcarp and shrimp was isolated $V$. parahaemoyticus (Alcaide et al. 1999; Liu et al. 2000; Choi et al. 2017).

Both species were also isolated from skin ulcers of $O$. joubini, but only $V$. alginolyticus was proved with ability to produce ulcers in this species $(1 \mathrm{~g})$ at concentrations of $10^{6}$ $\mathrm{CFU} \mathrm{ml} \mathrm{m}^{-1}$, after performing an incision on mantle in order to provide an invasion site for bacteria (Hanlon and Forsythe 1990). Furthermore, both species were also isolated from skin lesions of cultured $O$. vulgaris (Fichi et al. 2015). Small and larger lesions were detected (Fig. 8.2), showing a white appearance similar to those previously described (Hanlon 
Fig. 8.2 White skin lesion on head in an adult female of $O$. vulgaris cultured in Italy

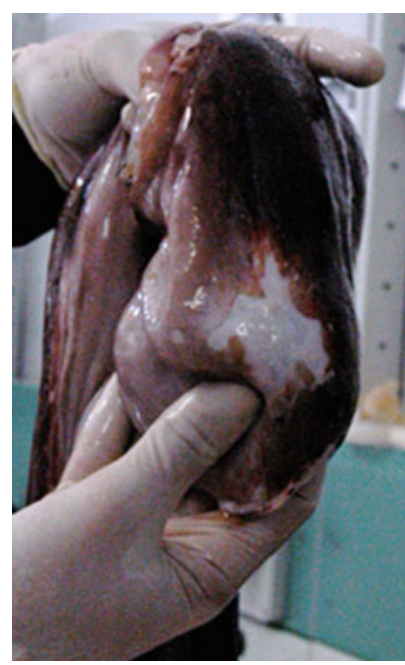

and Forshyte 1990; Farto et al. 2003). Moreover, it was also isolated from gill heart, evidencing their potential as invader. Similarly, it was shown for $V$. parahaemolyticus in squids and cuttlefish being isolated from haemolymph and other organs (Hanlon and Forshyte 1990; Sangster and Smolowitz 2003). In addition, to bacterial species, Aggregata octopiana oocysts and betanodavirus were also found in the same skin lesion (Fichi et al. 2015). Co-infection was previously shown as an enhancing factor for bacterial invasion in fish (Rodríguez-Quiroga et al. 2016).

Additionally, both species can infect humans. Whereas, the infections of $V$. alginolyticus are frequently associated with wound infections, external otitis or cellulitis, acute gastroenteritis are caused by $V$. parahamolyticus. The strains of $V$. parahaemolyticus affecting humans have the ability to produce a thermostable direct haemolysin (TDH) and/or a thermostable-related haemolysin (TRH). To date, these toxins have not been produced by most of strains associated with diseases in aquatic animals. On the other hand, there are limited studies on ability of human clinical isolates to cause diseases in marine organisms, but was proved that human clinical or environmental strains were infectious for both humans and abalones (Lee et al. 2003). On the contrary, recently, the lack of effectiveness in causing disease in a shrimp host was proved for human clinical strains (Choi et al. 2017). Differences between strains of $V$. alginolyticus affecting humans or marine organisms are still unavailable.

Both species swarm across TSA-1\% and completely covers the plate in $24 \mathrm{~h}$ at $22{ }^{\circ} \mathrm{C}$. Differences in colour of colonies are shown in TCBS, and they are yellow and green for $V$. alginolyticus and $V$. parahaemolyticus, respectively. Photographs of culture and microscopic appearance of organisms are detailed in texts such as Buller (2004).

They are also halophilic. Although most of them show an optimum growth with $\mathrm{NaCl}$ concentrations of $2-4 \%$ of $\mathrm{NaCl}$, particularly, $V$. alginolyticus is more tolerant to higher and lower concentrations. In fact, there is a well growth up to $8 \%$ of $\mathrm{NaCl}$ and $40 \%$ of strains were described with ability to grow also at $10 \% \mathrm{NaCl}$. On the contrary, $V$. parahamolyticus exhibits poor growth in media with $6 \% \mathrm{NaCl}$ and $10 \% \mathrm{NaCl}$ is inhibitory (Mechri et al. 2015). Moreover, both are able to growth between 15 and $42{ }^{\circ} \mathrm{C}$. Although they can live in a wide range of temperatures their growth is favoured by the increase of temperatures, and for example, in $V$. parahamolyticus their outbreak of diseases has been associated with thermal induction (Liu et al. 2000; Huang et al. 2001).

A fast preliminary identification is proposed through the number of steps described in Sect. 8.2 (Characterization of culturable bacteria). Other commercial identification systems (API ZYM, API 20NE, etc.) were also proposed for their identification. Although several of primers developed have cross-reaction with both species, specific primers were also proposed. Particularly, for $V$. alginolyticus that corresponding to the heat shock protein 40 , and for $V$. parahamoltycus PCR that detects a fragment (including a non-coding region and a phosphatidylserine synthetase gene) termed $\mathrm{R} 72 \mathrm{H}$ (Buller 2004; Mechri et al. 2015).

Sensitivity or resistance at the same antibiotic was shown by strains of both species depending on their origin. Both are resistant to a wide range of antibiotics commonly used in aquaculture (ampicillin, erythromycin, tetracycline, streptomycin and chloramphenicol). Flumequine and streptomycin are promising candidates for therapy against $V$. alginolyticus and V. parahamolyticus, respectively (Mechri et al. 2015). Alternative promising measures to antibiotics to prevent the diseases caused by these species such as the use of antibiofilm agents (palmitic acid, nanoparticles) were recently proposed (Chari et al. 2017; Santhakumari et al. 2017). Another hopeful treatment are the peptides produced by Bacillus subtilis which were proved with antimicrobial activity against both species, and in addition, had a protective effect against $V$. parahaemolyticus when they were incorporated into the diet of shrimps (Cheng et al. 2017). Water treatment by using photolysis therapy was effective in controlling V. parahamolyticus (Malara et al. 2017).

\section{Vibrio splendidus-related group (Splendidus clade)}

Splendidus clade, Vibrionaceae family, Gammaproteobacteria class, consists of a group of species phylogenically closely related with $V$. splendidus. To date, the species are: $V$. artabrorum, V. atlanticus, V. crassostreae, V. celticus, $V$. cortegadensis, V. cyclitrophicus, $V$. chagasii, $V$. fortis, V. gallaecicus, V. gigantis, $V$. hemicentroti $V$. kanaloae, $V$. lentus, $V$. pomeroyi, $V$. pelagius, $V$. splendidus, $V$. tasmaniensis and $V$. toranzoniae. Recently, it has been proposed the exclusion of 5 species (V. atlanticus, $V$. cortegadensis, $V$. chagasii, $V$. fortis, $V$. pelagius), but still they 

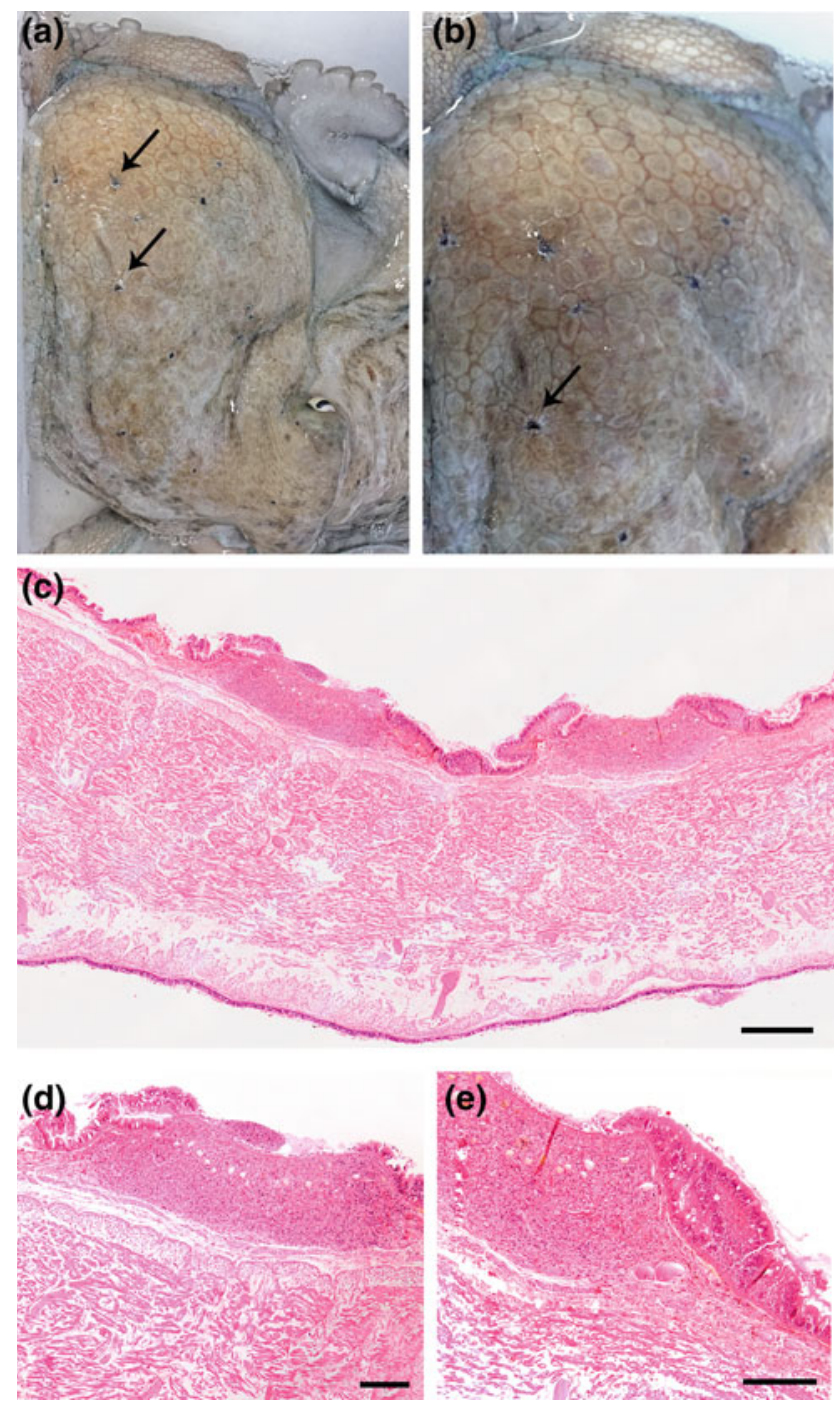

Fig. 8.3 O. vulgaris from maintained in aquarium conditions. a Macrophotography of the dorsal mantle showing small black spots on the skin. b Detail of small ulcers surrounding the black spots. c-d. Histological sections of the skin lesions showing ulceration and loss of skin epithelium (arrows) (c). Dense aggregations of bacteria, haemocyte infiltration and inflammation of the infected area (arrow heads) H\&E stain. Scale bars c, $500 \mu \mathrm{m}$; d, e $200 \mu \mathrm{m}$

form a clade composed of at least 13 species (Oden et al. 2016).

Most of them have been associated with marine organism's diseases, including molluscs (Sect. 8.2). In wild-caught $O$. vulgaris, without apparent damage, we frequently detected small black spots on their dorsal mantle, and in some occasions small ulcers surrounding the spots (Fig. 8.3a, b). Bacteria isolated, which were identified by using sequencing of $16 \mathrm{~S}$ rRNA gene, were closely related to $V$. splendidus/ $V$. atlanticus/ $V$. kanlaloae. However, when octopus were kept in the aquarium tanks, the ulcerations were much more evident and spread infection to head and arms, and also to other conspecifics sharing the tank. Death was not observed in any of animals at least for four months.

Histopathological lesions were characterized by dense aggregations of bacteria, ulceration, loss of skin epithelium, and haemocyte infiltration and inflammation of the infected area (Fig. 8.3c, d).

Splendidus clade includes gram-negative rods, motile and facultatively anaerobic bacteria with ability to growth on TCBS, ability to produce acid from a wide variety of substrates, and also with facility to grow by using an extensive number of substrates as sole carbon source. These lasts phenotypic features are the mainly basis to differentiate the species within Splendidus clade, but it is still difficult since variations in the same phenotypic test are reported among different strains included in the same species and different research groups.

A fast preliminary identification is proposed through the number of steps described in Sect. 8.2 (Characterization of culturable bacteria). Firstly, a phenotypical characterization with primary identification tests including the decarboxylases (ADH, LDC, ODC). Secondly, since Splendidus clade, is the most abundant in marine environment, the use primers VTS/VT and VTS/VS primer sets are a valuable tool for a fast detection of Splendidus clade. Finally, the 16S rRNA gene analyses are also a valuable tool to resolve distinct genera, but it is insufficient to discriminate closely related species such as those included in the Splendidus clade. If a final identification will be necessary, then a multilocus sequence analysis (MLSA) technique, which is based on the sequencing of multiple housekeeping genes, should be applied (Pérez-Cataluña et al. 2016; Oden et al. 2016).

The susceptibility of $V$. splendidus to several antibiotics was recorded (chloramphenicol, flumequine, nitrofurantoin, nifurpirinol, oxonic acid and potentiated sulphonamide), and their use was successful for the treatment of infection in fish (Revised by Austin et al. 2007). Chloramphenicol and gentamycin were also highly effective in the treatment of squids or cuttlefishes (Hanlon and Forsythe 1990). Recently, other alternative strategies to control an outbreak have been effective, such as the use of a combination of different phages ( $\mathrm{Li}$ et al. 2016). Treatments to control disease caused by other species of Splendidus clade are still unavailable.

\subsubsection{Miscellaneous Bacteria Associated with Eye Damages or Associated Tissues}

Previously, several Vibrio species were proved as invaders of squid eyes, having hardly affected the cornea. Particularly, $V$. anguillarum, $V$. charchariae or $V$. harveyi were cultured from the posterior chamber of squids. Furthermore, Micrococcus sp. was also detected in the vitreous humour, the posterior lens surface and the haemolymph of affected 
Fig. 8.4 Retrobulbar lesion in an adult male of $O$. vulgaris cultured in Italy: a White fluid material leaked from the retrobulbar lesion after the removal of the ocular bulb. b Retrobulbar-confined cavity (2-3 cm diameter) excised from the head

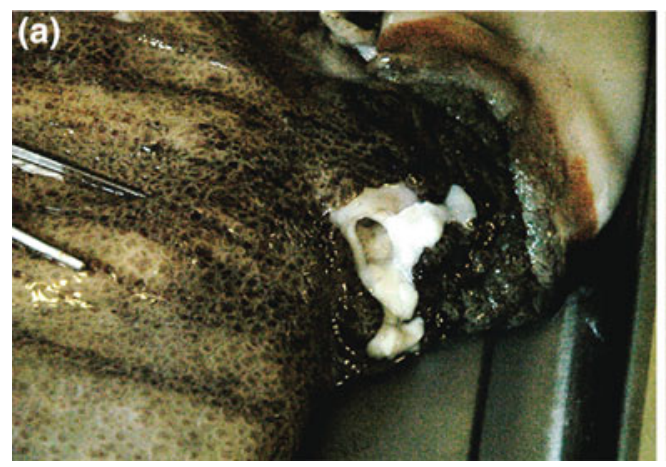

(b)

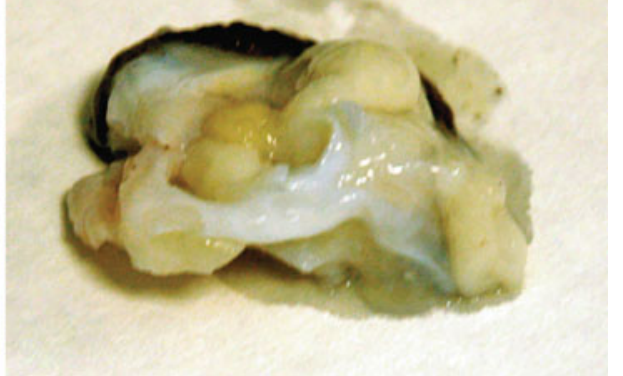

squids. Authors proposed a primarily involving damage to the cornea, which would be previous to the infection (Hanlon and Forsythe 1990). Recently, Ph. swingsii and L. garvieae were isolated from a white fluid material leaked from a retrobulbar lesion after the removal of the ocular bulb in an adult male common octopus. Until removing the ocular bulb, no gross lesion was observed. The lesion appeared as a confined cavity of 2-3 cm diameter (Fig. 8.4a, b).

\section{Lactococcus garvieae}

This is a gram-positive bacterium, which causes diseases in several aquatic and terrestrial animals (Tsai et al. 2012). In fish, it is responsible for hyperacute haemorrhagic septicaemia, but it has also been identified in bacterial outbreaks in aquatic invertebrates, such as the giant freshwater prawn, Macrobrchium rosenbergii (Vendrell et al. 2006; Tsai et al. 2012; Meyburgh et al. 2017). This bacterium has been reported in several species of fish, but it has also detected in other marine animals, such as a bottlenose dolphin, Tursiops truncatus (Evans et al. 2006) and a sea turtle, Caretta caretta (Fichi et al. 2016). Furthermore, it is considered an emerging pathogen related with handling or ingestion of raw fish and seafood for humans (Gibello et al. 2016). In cephalopods, $L$. garvieae was previously isolated in the muscle of a squid collected in a restaurant as the source of infection in a human endocarditis in Taiwan, but there was the possibility that the squid resulted positive for this bacterium due to a cross contamination with other raw fish (Wang et al. 2007).

L. garvieae, Streptococcaceae family, Bacilli class, is an ovoid coccus, not-motile, which grows from 4 to $45^{\circ} \mathrm{C}$, and at $6.5 \% \mathrm{NaCl}$ (Meyburgh et al. 2017), on several common media. On blood agar and Columbia-colistin-nalixic acid (CNA) agar, the colonies are small, white, alpha haemolytic and catalase negative. Several commercial identification systems, such as API strips, BD Phoenix, the Vitek system or MicroScan are able to identify it, but some strains can be misidentified as L. lactis or Enterococcus spp. (Gibello et al. 2016). A selective medium to differentiate L. garvieae, from other fish pathogen bacteria, called LG agar, has been developed by Chang et al. (2014). However, some molecular techniques, such PCR amplification of the internal transcribed spacer (ITS) region, sequencing of the $16 \mathrm{~S}$ rRNA gene, multiplex PCR and DNA microarray have been developed and allow to identify L. garvieae (Chang et al. 2014; Gibello et al. 2016; Meyburgh et al. 2017).

The treatment of L. garvieae infection in fish is based on lincomycin, oxytetracycline and macrolide antibiotics. A characteristic of this bacterium is the resistance to clindamycin, but resistance to erythromycin, streptomycin, tetracycline, oxytetracycline, florfenicol and some quinolones have also been reported (Gibello et al. 2016).

\section{Photobacterium swingsii}

This is a motile gram-negative small coccobacillus in Vibrionaceae family, Gammaproteobacteria class. It has been isolated and characterized for the first time from oysters during a vibriosis in Mexico and from the haemolymph of wild spider crabs collected in Canary Islands, Spain, by Gómez-Gil et al. (2011). It grows in TCBS agar, TSA supplemented up $2 \% \mathrm{NaCl}$ (TSA-2), marine agar, and blood agar in the temperature range of $4-37{ }^{\circ} \mathrm{C}$, and in the salt concentration range from 3 to $6 \%$ (Gómez-Gil et al. 2011, Fichi et al. 2015). In TCBS, the colonies of Ph. swingsii are green, small, round with smooth border, 2-3 mm diameter, while in TSA-2 and marine agar they are white (Gómez-Gil et al. 2011; Fichi et al. 2015). Some differences were observed among the six strains isolated by Gómez-Gil et al. (2011), regarding the growth conditions and the biochemical reactions.

The strain isolated from octopus grew from 22 to $37^{\circ} \mathrm{C}$ and at the $3 \%$ salt concentration and it tested positive for oxidase and catalase, and it is possible the identification by API $20 \mathrm{E}$ or API 20NE systems. The identification of $P h$. swingsii was applied by the sequencing of $16 \mathrm{~S}$ rRNA gene. By the fact that this bacterium has been isolated from oysters during a vibriosis outbreak and from a retrobulbar lesion in 
Fig. 8.5 O. vulgaris gills maintained in aquarium conditions. Histological sections of an adult showing rickettsiales-like organisms (arrows) at the base of the gill epithelium with distension of the basal membrane and hypertrophy of the infected cell. H\&E stain. Scale bars $\mathbf{a} 100 \mu \mathrm{m} ; \mathbf{b} 50 \mu \mathrm{m}$
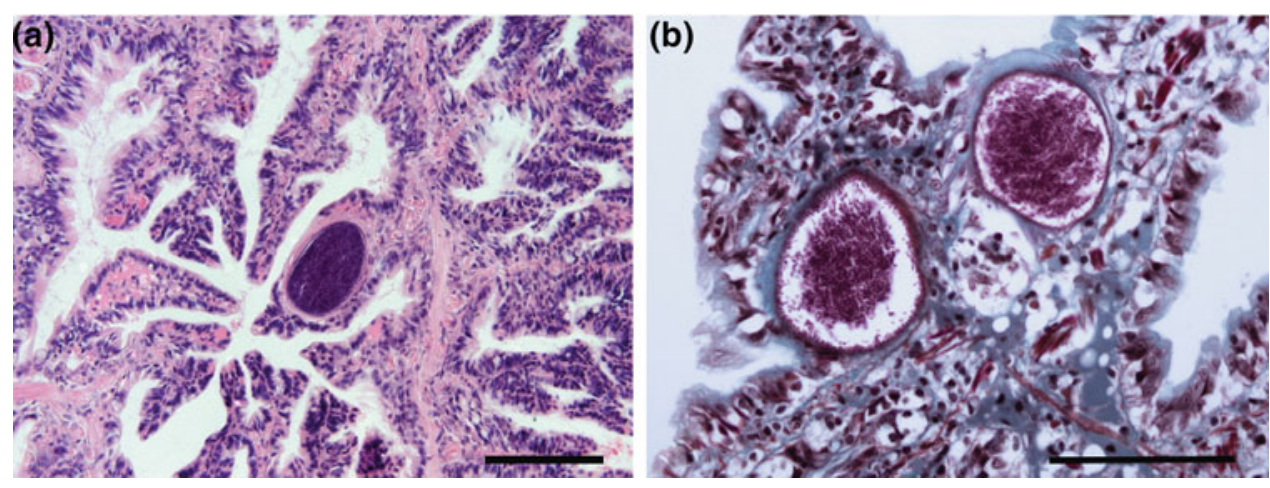

the common octopus, there are strong evidences of its pathogenic role, but this should be confirmed by an experimental infection.

The isolated strain resulted susceptible to the vibrio static O129 at 10 and $150 \mu \mathrm{g}$, but no other antibiotic test susceptibility was performed.

\subsubsection{Rickettsial-like Organisms (RLO)}

RLO are gram-negative bacteria, which have been associated with infection and mass mortalities in several aquatic animals. Particularly, cases of molluscs bivalves have increased since the first description in clams was reported (Azevedo et al. 2006; revised by Romalde and Barja 2010; Ceuta and Boehs 2012; revised by Gollas-Galván et al. 2014). These organisms have been found mainly within the epithelial cells of the mantle, gills digestive gland, connective tissue and hepatopancreas of several molluscs (revised by Gollas-Galván et al. 2014).

Similarly, they were detected in the gills of the common octopus $O$. vulgaris. They were observed like basophilic intracytoplasmatic microcolonies of about $102 \mu \mathrm{m}(70-150)$ infecting the epithelial cells of the gills (Fig. 8.5a). Invaded host cells became hyperthophic (Fig. 8.5b) and necrosis were occasionally observed (Gestal et al. 1998). No significant harm or signs of disease have been observed in the hosts, since usually a few cells were affected. However, conditions of stress, high animal density or crowding system under intensive rearing increased the occurrence of diseases. Under these conditions, RLO were able to have a detrimental effect on the respiratory gaseous exchange of the octopus and special attention and controls were needed.

RLO are obligate intracellular organisms, highly fastidious, non-motile, non-spore-forming and highly pleomorphic. Unfortunately, artificial media to isolate these organisms are still unavailable for most of them, being difficult their isolation and characterization. To date, only one species was able to grow on agar plates or broth (revised by Gollas-Galván et al. 2014).
Light microscopic examinations of paraffin sections or indirect immunofluorescence with specific immune serum are the methods used for their identification. Sequencing of 16S, internal transcribed spacer (ITS) or 23S ribosomal DNA sequencing are also strategies used to characterize these bacteria. Moreover, some specific primers set have been developed to identify Rickettsia in salmonids (Mauel et al. 1996).

Limited studies about treatment of RLO to control disease are published. The supply of medicated feed (oxytetracycline and florfenicol) was effective for the treatment against the necrotizing hepatopancreatitis bacterium (NHPB), which is a RLO-affecting crustaceans (Gollas-Galván et al. 2014).

\subsection{Pathogenic Bacteria for Adults}

In this section, a brief reference to those bacteria confirmed as the causative agent of diseases and mortality in octopus are included.

\subsubsection{Vibrio lentus}

This is a gram-negative bacterium, which was firstly described as an environmental species being associated to reared Mediterranean oyster (Macián et al. 2001), and later also associated with larvae cultures of scallops, and turbot (Le Roux et al. 2004). Studies to assess the diversity of bacteria based on 16S rRNA showed that this species seems to be also associated with mussel or adult turbot hatcheries, and surface of algae (Montes et al. 2006; Wang et al. 2009; Kwan and Bolch et al. 2015). Moreover, it is one of the intestinal autochthonous bacteria from the intestinal tract of the common carp (Chi et al. 2014), and recently it was revealed as a protective agent against vibriosis caused by $V$. harveyi in gnotobiotic sea bass larvae (Schaeck et al. 2016). On the contrary, this species was also associated with lesions in lobsters (Chistoserdov et al. 2005) or octopus. Particularly, in octopus, $V$. lentus was isolated from skin lesions and the gill heart of diseased individual captured from their 
Fig. 8.6 V. lentus on plates, $48 \mathrm{~h}, 22^{\circ} \mathrm{C}$. a TSA-2. b TCBS
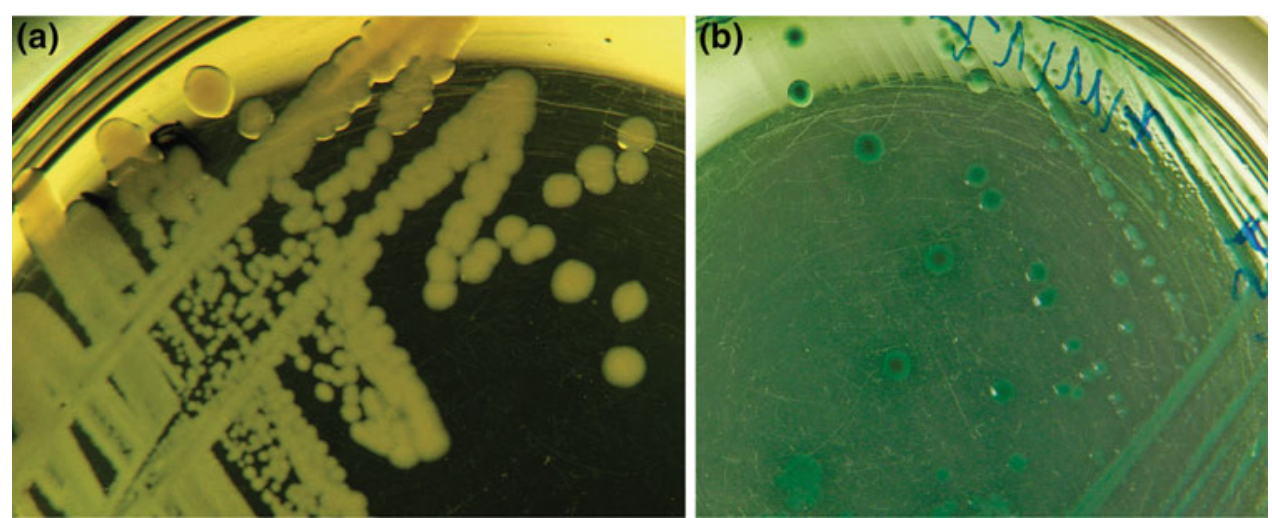

natural marine environment, and it was able to induce both skin lesions and mortality in healthy octopuses $(0.5-1 \mathrm{~kg})$ maintained in the laboratory (Farto et al. 2003).

The signs caused by bacteria in octopuses were round hard lesions in the arm or head mantle, which can evolve to skin losing and muscle beneath exposition when the time is advancing. These symptoms were similar to those of stages 3 and 4 of the disease described by Hanlon and Forsythe (1990) for O. joubini. In addition, the bacteria was able to colonize gill heart, and induce lesions and mortality after $72 \mathrm{~h}$ of exposition, depending on immunity of each individual (Farto et al. 2003).

V. lentus, Vibrionaceae family, Gammaproteobacteria class, is a rod-shaped bacteria, motile, unable to growth at $37{ }^{\circ} \mathrm{C}$ or with $7 \%$ of $\mathrm{NaCl}$. It shows $0.2-0.4 \mathrm{~mm}$ colonies, which are, round, transparent, non-pigmented and unable to swarm after $48 \mathrm{~h}$ on TSA-2 at $22{ }^{\circ} \mathrm{C}$ (Fig. 8.6a); on TCBS, the colonies are green (Fig. 8.6b). Other phenotypical characteristics were previously described in detail (Macián et al. 2001; Farto et al. 2003).

This species is closely related to other species, which are all included in the Splendidus clade. Specific primers have not been developed, and the number of steps described in Sect. 8.2.1 (Splendidus clade) is suggested for their identification.

$V$. lentus showed a wide antimicrobial susceptibility pattern, having the highest, with amoxicyllin, cefotaxime, chloramphenicol or piperacillin (Farto et al. 2003). Safer strategies, such as probiotics or others, are still unavailable, for the treatment of infection in octopus.

\subsection{Concluding Remarks}

To date, different species of Vibrio and new potential pathogens (most of them previously reported as causal agents of high losses in hatcheries as well as in natural beds in aquaculture of molluscs) have been shown associated with different stages of cultured or aquarium-maintained cephalopods. However, it is still unknown if most of them are the initial cause of infection.

To understand the equilibrium among a community of microorganisms, and how changes in husbandry practices select for more virulent genotypes are important targets to be addressed in the future.

Prevention techniques are needed to avoid bacterial infections in cephalopods maintained in aquarium systems, which include good welfare practices, cleaning of tanks and control of water and food quality supplied. However, once the presence of the pathogen is confirmed, treatments to combat the infection are needed. To date, most of treatments to control diseases caused by bacteria-affecting cephalopods are based on applying antibiotics. This therapy is becoming more restrictive as a consequence of generating multi-drug resistant pathogens and accumulation of toxic compounds in farmed organisms, causing long-term adverse health effect to humans and other animals. Therefore, special attention should be focussed on the use of alternative methods in order to protect larvae, juvenile and adult cephalopods against pathogens and improve their survival, and also safeguard human health and environment.

Acknowledgements Authors would like to thank Raquel Fernández-Gago (University of Vigo) who has generously donated images (Fig. 8.1a, b) and tissue sections of bacterial-infected $O$. vulgaris parlarvae, and María Gómez-Costas (University of Vigo) who has collaborated in Sect. 8.2.

\section{References}

Alcaide E, Amaro C, Todolí R, Oltra R (1999) Isolation and characterization of Vibrio parahaemolyticus causing infection in Iberian toothcarp Aphanius iberus. Dis Aquat Org 35:77-80

Anguiano-Beltrán C, Searcy-Bernal R, Lizárraga-Partida M (1998) Pathogenic effects of Vibrio alginolyticus on larvae and postlarvae of the red abalone Haliotis rufescens. Dis Aquat Org 33:119-122 
Austin B, Austin D, Sutherland R, Thompson F, Swings J (2005) Pathogenicity of vibrios to rainbow trout (Oncorhynchus mykiss, Walbaum) and Artemia nauplii. Environ Microbiol 7:1488-1495

Azevedo C, Conchas RF, Tajdari J, Montes M (2006) Ultrastructural description of new Rickettsia-like organisms in the commercial abalone Haliotis tuberculata (Gastropoda: Haliotidae) from the NW of Spain. Dis Aquat Org 71:233-237

Beaz-Hidalgo R, Cleenwerck I, Balboa S, De Wachter M, Thompson F, Swings J, DeVos P, Romalde JL (2008) Genomic diversity amongst Vibrio isolates associated with clam culture in Galicia (NW of Spain). Syst Appl Microbiol 31:215-222

Beaz-Hidalgo R, Doce A, Pascual J, Toranzo AE, Romalde JL (2009) Vibrio gallaecicus sp. nov. isolated from cultured clams in north-western Spain. Syst Appl Microbiol 32:111-117

Borges MT, Sousa A, De Marco P, Matos A2, Hönigová P, Castro PML (2008) Aerobic and anoxic growth and nitrate removal capacity of a marine denitrifying bacterium isolated from a recirculation aquaculture system. Microb Ecol 55:107-118

Buller NB (2004) Bacteria from fish and other aquatic animals: a practical identification manual. CABI Publishing, UK

Cervino JM, Thompson FL, Gomez-Gil B, Lorence EA, Goreau TJ, Hayes RL, Winiarski-Cervino KB, Smith GW, Hughen K, Bartels E (2008) The Vibrio core group induces yellow band disease in Caribbean and Indo-Pacific reef-building corals. J Appl Microbiol 105:1658-1671

Ceuta L, Boehs G (2012) Parasites of the mangrove mussel Mytella guyanensis (Bivalvia: Mytilidae) in Camamu Bay, Bahia, Brazil. Braz J Biol 72:421-427

Chang C-I, Lee C-F, Tsai J-M, Wu C-C, Chen L-H, Chen S-C, Lin K-J (2014) Development of a selective and differential medium for capsulated Lactococcus garvieae. J Fish Dis 37:719-728

Chari N, Felix L, Davoodbasha M, Sulaiman Ali A, Nooruddin T (2017) In vitro and in vivo antibiofilm effect of copper nanoparticles against aquaculture pathogens. Biocatal Agric Biotechnol 10:336-341

Cheikh YB, Travers MA, Morga B, Godfrin Y, Rioult D, Le Foll F (2016) First evidence for a Vibrio strain pathogenic to Mytilus edulis altering hemocyte immune capacities. Dev Comp Immunol 57:107-119

Cheng A-Ch, Lin H-L, Shiu Y-L, Tyan Y-Ch, Ch-H (2017) Isolation and characterization of antimicrobial peptides derived from Bacillus subtilis E20-fermented soybean meal and its use for preventing Vibrio infection in shrimp aquaculture. Fish \& Shellfish Immunol 67:270-279

Chistoserdov AY, Smolowitz R, Mirasol F, Hsu A (2005) Culture-dependent characterization of the microbial community associated with epizootic shell disease lesions in american lobster, Homarus americanus. J Shellfish Res 24:741-747

Choi M, Stevens AM, Smith SA, Taylor DP, Kuhn DD (2017) Strain and dose infectivity of Vibrio parahaemolyticus: the causative agent of early mortality syndrome in shrimp. Aquacult Res 48:3719-3727

Evans JJ, Pasnik DJ, Klesius PH, Al-Ablani S (2006) First report of Streptococcus agalactiae and Lactococcus garvieae from a wild bottlenose dolphin (Tursiops truncates). J Wild Dis 42:561-569

Farto R, Armada SP, Montes M, Guisande JA, Pérez MJ, Nieto TP (2003) Vibrio lentus associated with diseased wild octopus (Octopus vulgaris). J Invertebr Pathol 83:149-156

Farto R, Montes M, Guisande JÁ, Armada SP Prado S, Nieto TP (2006) An improved and rapid biochemical identification of indigenous aerobic culturable bacteria associated with Galician oyster production. J Shellfish Res 25:1059-1066

Fichi G, Cardeti G, Perrucci S, Vanni A, Cersini A, Lenzi C, De Wolf T, Fronte B, Guarducci M, Susini F (2015) Skin lesion-associated pathogens from Octopus vulgaris: first detection of Photobacterium swingsii, Lactococcus garvieae and betanodavirus. Dis Aquat Org 115:147-56
Fichi G, Cardeti G, Cersini A, Mancusi C, Guarducci M, Di Guardo G, Terracciano G (2016) Bacterial and viral pathogens detected in sea turtles stranded along the coast of Tuscany, Italy. Vet Microbiol 185:56-61

García-Fernández P, Castellanos-Martínez S, Iglesias J, Otero JJ, Gestal C (2016) Selection of reliable reference genes for RT-qPCR studies in Octopus vulgaris paralarvae during development and immune-stimulation. J Invertebr Pathol 138:57-62

Gestal C, Abollo E, Pascual S (1998) Rickettsiales-like organisms in the gills of reared Octopus vulgaris (Mollusca, Cephalopoda). Bull Eur Ass Fish Pathol 18:13-14

Gibello A, Galán-Sánchez F, Mar Blanco M, Rodríguez-Iglesias M, Domínguez L, Fernández-Garayzábal JF (2016) The zoonotic potential of Lactococcus garvieae: An overview on microbiology, epidemiology, virulence factors and relationship with its presence in foods. Res Vet Sci 109:59-70

Gollas-Galván T, Avila-Villa LA, Martínez-Porchas M, Hernández-López J (2014) Rickettsia-like organisms from cultured aquatic organisms, with emphasis on necrotizing hepatopancreatitis bacterium affecting penaeid shrimp: An overview on an emergent concern. Rev Aquacult 6:256-269

Gómez-Gil B, Roque A, Rotllant G, Peinado L, Romalde JL, Doce A, Cabanillas-Beltra H, Chimetto LA, Thompson FL (2011) Photobacterium swingsii sp. nov., isolated from marine organisms. Int J Syst Evol Microbiol 61:315-319

Gómez-León J, Villamil L, Lemos ML, Novoa B, Figueras A (2005) Isolation of Vibrio alginolyticus and Vibrio splendidus from aquacultured carpet shell clam (Ruditapes decussatus) larvae associated with mass mortalities. Appl Environ Microbiol 71:98-104

Guisande JA, Lago EP, Prado S, Nieto TP, Farto R (2008) Genotypic diversity of culturable Vibrio species associated with the culture of oysters and clams in Galicia and screening of their pathogenic potential. J Shellfish Res 27:801-809

Guisande JA, Montes M, Farto R, Armada SP, Pérez MJ, Nieto TP (2004) A set of test for the phenoypic identification of culturable bacteria associated with Galician bivalve mollusc production. J Shellfish Res 23:599-609

Hanlon RT, Forsythe W (1990) Diseases of Mollusca: Cephalopoda. 1.1. Diseases caused by microorganisms. In: Kinne O (ed) Diseases of marine animals, vol III. Hamburg, Biologische Anstalt Helgoland, pp 21-46

Harder T (2009) Marineepibiosis: concepts, ecological consequences and host defence. Mar Ind Biofouling 4:219-231

Huang C-Y, Liu P-C, Lee K-K (2001) Withering syndrome of the small abalone, Haliotis diversicolor supertexta, is caused by Vibrio parahaemolyticus and associated with thermal induction. Z Naturforsch (C) 56:898-901

Iehata S, Valenzuela F, Riquelme C (2016) Evaluation of relationship between Chilean octopus (Octopus mimus Gould, 1852) egg health condition and the egg bacterial community. Aquacult Res 47:649-659

Iglesias J, Otero JJ, Moxica C, Fuentes L, Sánchez FJ (2004) The completed life cycle of the octopus (Octopus vulgaris, Cuvier) under culture conditions: paralarval rearing using Artemia and zoeae, and first data on juvenile growth up to 8 months of age. Aquacult Int 12:481-487

Jayaprakash NS, Pai SS, Philip R, Singh ISB (2006) Isolation of a pathogenic strain of Vibrio alginolyticus from necrotic larvae of Macrobrachium rosenbergii (de Man). J Fish Dis 29:187-191

Kwan TN, Bolch CJS (2015) Genetic diversity of culturable Vibrio in an Australian blue mussel Mytilus galloprovincialis hatchery. Dis Aquat Org 116:37-46

Lago EP, Nieto TP, Farto R (2009) Fast detection of Vibrio species potentially pathogenic for mollusc. Vet Microbiol 139:339-346 
Le Roux FL, Gay M, Lambert Ch, Nicolas JL, Gouy M, Berthe F (2004) Phylogenetic study and identification of Vibrio splendidus-related strains based on gyrB gene sequences. Dis Aquat Org 58:143-150

Lee KK, Liu P-C, Huang C-Y (2003) Vibrio parahaemolyticus infectious for both humans and edible mollusk abalone. Microbes Infect 5:481-485

Li Z, Xiaoyu L, Jiancheng Z, Xitao W, Lili W, Zhenhui C, Yongping X (2016) Use of phages to control Vibrio splendidus infection in the juvenile seacucumber Apostichopus japonicas. Fish Shellfish Immunol 54:302-311

Liu P-C, Chen Y-C, Huang C-Y, Lee K-K (2000) Virulence of Vibrio parahaemolyticus isolated from cultured small abalone, Haliotis diversicolor supertexta, with withering syndrome. Lett Appl Microbiol 31:433-437

Liu PC, Ji-Yang L, Pei-Tze H, Kuo-Kau L (2004) Isolation and characterization of pathogenic Vibrio alginolyticus from diseased cobia Rachycentron canadum. J Basic Microbiol 44:23-28

Macián MC, Ludwig W, Aznar R, Grimont PA, Schleifer KH, Garay E, Pujalte MJ (2001) Vibrio lentus sp. nov., isolated from Mediterranean oysters. Int J Syst Evol Microbiol 51:1449-1456

Maeda M, Nogami K, Kanematsu M, Hirayama K (1997) The concept of biological control methods in aquaculture. Hydrobiologia 358:285-290

Malara D, Mielke Ch, Oelgemöller M, Senge MO, Heimann K (2017) Sustainable water treatment in aquaculture - photolysis and photodynamic therapy for the inactivation of Vibrio species. Aquacult Res 48:2954-2962

Mauel MJ, Giovannoni SJ, Fryer JL (1996) Development of polymerase chain reaction assays for detection, identification, and differentiation of Piscirickettsia salmonis. Dis Aquat Org 26:189-195

Maximilien R, de Nys R, Holmström C, Gram L, Givskov M (1998) Chemical mediation of bacterial surface colonisation by secondary metabolites from the red alga Deliseapulchra. Aqua Microb Ecol 15:233-246

Mechri B, Salem IM, Medhioub A, Medhioub MN, Aouni M (2012) Diversity of Vibrionaceae associated with Ruditapes decussatus hatchery in Tunisia. Ann Microbiol 61:597-606

Mechri B, Salem IM, Medhioub A, Medhioub MN, Aouni M (2015) Isolation and genotyping of potentially pathogenic Vibrio alginolyticus associated with Ruditapes decussatus larva and juvenile mass mortalities. Aquacult Int 23:1033-104

Meyburgh CM, Bragg RR, Boucher CE (2017) Lactococcus garvieae: an emerging bacterial pathogen of fish. Dis Aquat Org 123:67-79

Montes M, Farto R, Pérez MJ, Armada SP, Nieto TP (2006) Genotypic diversity of Vibrio isolates associated with turbot (Scophthalmus maximus) culture. Res Microbiol 157:487-495

Montes M, Farto R, Pérez MJ, Nieto TP, Larsen JL, Christensen H (2003) Characterization of Vibrio Strains Isolated from turbot (Scophthalmus maximus) culture by phenotypic analysis, ribotyping and 16S rRNA gene sequence comparison. J Appl Microbiol 95:693-703

Montes M, Pérez MJ, Nieto TP (1999) Numerical taxonomy of Gram-negative, facultative anaerobic bacteria isolated from skin of Turbot (Scophthalmus maximus) and surrounding water. System Appl Microbiol 22:604-618

Nicolas JL, Corre S, Gauthier G, Robert R, Ansquer D (1996) Bacterial problems associated with scallop Pecten maximus larval culture. Dis Aquat Org 27:67-76

Oden E, Burioli EAV, Trancart S, Pitel PH, Houssina M (2016) Multilocus sequence analysis of Vibrio splendidus related-strains isolated from blue mussel Mytilus sp. during mortality events. Aquaculture 464:420-427

Parsek MR, Greenberg EP (2005) Socio Microbiol: the connections between quorum sensing and biofilms. Trends Microbiol 13:27-33
Pérez-Cataluña A, Lucena T, Tarazona E, Arahal DR, Macián MC, Pujalte MJ (2016) An MLSA approach for the taxonomic update of the Splendidus clade, a lineage containing several fish and shellfish pathogenic Vibrio spp. System Appl Microbiol 39:361-369

Popovic NT, Coz-Rakovac R, Strunjak-Perovic I (2007) Commercial phenotypic tests (API 20E) in diagnosis of fish bacteria: a review. Vet Med 52:49-53

Prado S, Romalde JL, Montes J, Barja JL (2005) Pathogenic bacteria isolated from disease outbreaks in shellfish hatcheries. First description of Vibrio neptunius as an oyster pathogen. Dis Aquat Org 67:209-215

Pujalte MJ, Ariadna Sitjà-Bobadilla A, Macián MC, Álvarez-Pellitero P, Garay E (2007) Occurrence and virulence of Pseudoalteromonas spp. in cultured gilthead sea bream (Sparus aurata L.) and European sea bass (Dicentrarchus labrax L.). Molecular and phenotypic characterisation of $P$. undina strain U58. Aquaculture 271:47-53

Riquelme C, Toranzo AE, Barja J, Vergara N, Araya R (1996) Association of Aeromonas hydrophila and Vibrio alginolyticus with larval mortalities of scallop (Argopecten purpuratus). J Invertebr Pathol 67:213-218

Rodríguez Quiroga JJ, Ferreiro A, Iglesias R, García Estévez JM, Farto R, Nieto TP (2016) Susceptibility of turbot to Aeromonas salmonicida subsp. salmonicida during a mixed experimental infection with Philasterides dicentrarchi. Bull Eur Ass Fish Pathol $36: 118-125$

Romalde JL, Barja JL (2010) Bacteria in molluscs: good and bad guys. In: Méndez-Vilas A (ed) Current research, technology and education topics in applied microbiology and microbial biotechnology, pp 136-147. Formatex Research Center, Badajoz

Roura A, Doyle S R, Nande M, Strugnell JM (2017) You Are What You Eat: A Genomic Analysis of the Gut Microbiome of Captive and Wild Octopus vulgaris Paralarvae and Their Zooplankton Prey. Front Physiol 8:Article 362

Sandaa R, Laila B, Thorolf M, Øivind B (2008) Monitoring the opportunistic bacteria Pseudoalteromonas sp. LT-13 in a great scallop, Pecten maximus hatchery. Aquaculture 276:14-21

Sangster CR, Smolowitz RM (2003) Description of Vibrio alginolyticus infection in cultured Sepia officinalis, Sepia apama, and Sepia pharaonic. Biol Bull 205:233-234

Santhakumaria S, Nilofernishaa NM, Ponrajb JG, Pandiana SK, Ravia AV (2017) In vitro and in vivo exploration of palmitic acid from Synechococcus elongatus as an antibiofilm agent on the survival of Artemia franciscana against virulent vibrios. J Invertebr Pathol 150:21-31

Sawabe T, Kita-Tsukamoto K, Thompson FL (2007) Inferring the evolutionary history of Vibrios by means of multilocus sequence analysis. J Bacteriol 189:7932-7936

Schaeck M, Duchateau L, Van den Broeck W, Van Trappen S, De Vos P, Coulombet C, Boon N, Haesebrouck F, Decostere A (2016) Vibrio lentus protects gnotobiotic sea bass (Dicentrarchus labrax L.) larvae against challenge with Vibrio harveyi. Vet Microbiol $185: 41-48$

Sharp KH, Eam B, Faulkner DJ, Haygood MG (2007) Vertical transmission of diverse microbes in the tropical sponge Corticium sp. Appl Environ Microbiol 73:622-629

Sherrill J, Spelman LH, Reidel CL, Montali RJ (2000) Common cuttlefish (Sepia officinalis) mortality at the national zoological park: Implications for clinical management. J Zoo Wildlife Med 31:523-531

Shi L-y, Liang S, Luo X, Ke C-h, Zhao J (2017) Microbial community of Pacific abalone (Haliotis discus hannai) juveniles during a disease outbreak in South China. Aquacult Res 48:1080-1088 
Snoussi M, Chaieb K, Mahmoud R, Bakhrouf A (2006) Quantitative study, identification and antibiotics sensitivity of some Vibrionaceae associated to a marine fish hatchery. Ann Microbiol 56:289-293

Tamura K, Stecher G, Peterson D, Filipski A, Kumar S (2013) MEGA6: molecular evolutionary genetics analysis version 6.0. Mol Biol Evol 30:2725-2729

Sykes AV, Gestal C (2014) Welfare and diseases under culture conditions. In: Iglesias J, Fuentes L, Villanueva R (eds) Cephalopod culture. Springer, Dordrecht, pp 97-112

Thakur NL, Anil AC, Müller WEG (2004) Culturable epibacteria of the marine sponge Ircinia fusca: temporal variations and their possible role in the epibacterial defense of the host. Aquat Microb Ecol 37:295-304

Thompson FL, Lida T, Swings J (2004) Biodiversity of vibrios. Microbiol Mol Rev 68:403-431

Thompson JR, Pacocha S, Pharino C, Klepac-Ceraj V, Hunt DE, Benoit J, Sarma-Rupavtarm R, Diste DL, Polz MF (2005) Genotypic diversity within a natural coastal bacterioplankton population. Science 307:1311-1313

Tsai MA, Wang PC, Liaw LL, Yoshida T, Chen SC (2012) Comparison of genetic characteristics and pathogenicity of Lactococcus garvieae isolated from aquatic animals in Taiwan. Dis Aquat Org 102:43-51

Uriarte I, Iglesias J, Domingues P, Rosas C, Viana MT, Navarro JC, Seixas P, Vidal E, Ausburger A, Pereda S, Godoy F, Paschke K, Farías A, Olivares A, Zuñniga O (2011) Current status and bottle neck of octopod aquaculture: the case of American species. J World Aquacult Soc 42:735-752

Vanhove AS, Duperthuy M, Charrière GM, Le Roux F, Goudenège D, Gourbal B, Kieffer-Jaquinod S, Couté Y, Wai SN, Destoumieux-Garzón D (2015) Outer membrane vesicles are vehicles for the delivery of Vibrio tasmaniensis virulence factors to oyster immune cells. Environ Microbiol 17:1152-1165

Vendrell D, Balcàzar JL, Ruiz-Zarzuela I, de Blas I, Gironés O, Múzquiz JL (2006) Lactococcus garvieae in fish: a review. Comp Immunol Microbiol Infect Dis 29:177-198

Verschuere L, Dhont J, Sorgeloos P, Verstraete W (1997) Monitorin Biolog patterns and $r / K$-strategists in the intensive culture of Artemia juveniles. J Appl Microbiol 83:603-612

Verschuere L, Heang H, Criel G, Sorgeloos P, Verstraete W (2000) Selected bacterial strains protect Artemia spp. from the pathogenic effects of Vibrio proteolyticus CW8T2. Appl Environ Microbiol 66:1139-1146

Wahl M, Goecke F, Labes A, Dobretsov S, Weinberger F (2012) The second skin: ecological role of epibiotic biofilms on marine organisms. Front Microbiol 3:1-21

Wang CY, Shie HS, Chen SC, Huang JP, Hsieh IC, Wen MS, Lin FC, Wu D (2007) Lactococcus garvieae infections in humans: possible association with aquaculture outbreaks. Int J Clin Pract 61:68-73

Wang Z, Xiao T, Pang S, Liu M, Yue H (2009) Isolation and identification of bacteria associated with the surfaces of several algal species. Chin J Oceanol Limnol 27:487-492

Xu SL, Dan-Li W, Chao-Yan J, Shan J, Chun-Lin W, Xiu Z (2013) Effects of Vibrio alginolyticus infection on immune-related enzyme activities and ultrastructure of Charybdis japonica gills. Aquaculture 396-399:82-88

Zheng F, Liu H, Zhang Y, Xu Z, Wang B (2017) Identification and characterization of pathogens associated with fin erubescence and ulceration of cultured Scophthalmus maximus. Aquacult Res 48:521-530
Open Access This chapter is licensed under the terms of the Creative Commons Attribution 4.0 International License (http://creative commons.org/licenses/by/4.0/), which permits use, sharing, adaptation, distribution and reproduction in any medium or format, as long as you give appropriate credit to the original author(s) and the source, provide a link to the Creative Commons licence and indicate if changes were made.
The images or other third party material in this chapter are included in the chapter's Creative Commons licence, unless indicated otherwise in a credit line to the material. If material is not included in the chapter's Creative Commons licence and your intended use is not permitted by statutory regulation or exceeds the permitted use, you will need to obtain permission directly from the copyright holder. 